\title{
Corneal Hysteresis in Thais and Variation of Corneal Hysteresis in Glaucoma
}

\author{
Kulawan Rojananuangnit \\ Glaucoma Unit, Ophthalmology \\ Department, Mettapracharak (Wat Rai \\ Khing) Hospital, Nakhon Pathom, \\ Thailand
}

Purpose: To collect the normal value data of corneal hysteresis in Thais and study the variation of corneal hysteresis in glaucomatous eyes.

Methods: Retrospective cross-sectional study of corneal hysteresis $(\mathrm{CH})$ in healthy nonglaucomatous and glaucomatous eyes. Demographic data, type and staging of glaucoma, Goldmann applanation tonometry (GAT) and ocular response analyzer parameters; $\mathrm{CH}$, cornealcompensated intraocular pressure (IOPcc) and Goldmann-correlated intraocular pressure (IOPg) were collected.

Results: Data from one eye of 465 normal participants were included for the normal value data of $\mathrm{CH}$. Mean CH, IOPcc and IOPg were $10.18 \pm 1.48,15.01 \pm 3.04$ and $14.16 \pm 3.06 \mathrm{mmHg}$, respectively. Average age was $57.21 \pm 14.4$ years. $\mathrm{CH}$ at the fifth percentile was $8.0 \mathrm{mmHg}$. Women had significantly higher $\mathrm{CH}$ than men $(10.29 \pm 1.46$ vs $9.90 \pm 1.49 \mathrm{mmHg}, \mathrm{p}=0.009)$. Moderate negative correlation was found between age and $\mathrm{CH}, r=-0.338, \mathrm{p}<0.001$. There were 695 glaucomatous eyes from 429 patients including primary-open angle glaucoma (POAG), primary close-angle glaucoma (PACG), normal tension glaucoma (NTG) and ocular hypertension (OHT). $\mathrm{CH}$ in each glaucoma type and severity stage (early, moderate and severe) were as follows: POAG: $8.74 \pm 1.52 \mathrm{mmHg}(9.22 \pm 1.47,8.74 \pm 1.23$ and $7.92 \pm 1.40 \mathrm{mmHg}, \mathrm{p}<0.001)$, PACG: $9.09 \pm 1.72 \mathrm{mmHg}(9.85 \pm 1.45,9.04 \pm 1.68$ and $8.45 \pm 1.74 \mathrm{mmHg}, \mathrm{p}=0.004)$, NTG: $9.55 \pm 1.67$ $\mathrm{mmHg}(9.47 \pm 1.38,9.75 \pm 2.42$ and $9.77 \pm 1.34 \mathrm{mmHg}, \mathrm{p} 0.525)$ and OHT: $10.10 \pm 1.40 \mathrm{mmHg}$. Conclusion: Compared with normal value data of corneal hysteresis, $\mathrm{CH}$ in glaucomatous eyes was lower. The more advanced glaucoma stage was associated with lower $\mathrm{CH}$. Arising from normal value data, a low percentile of $\mathrm{CH}$ could be applied as the deviation value from normal and this dynamic property of $\mathrm{CH}$ could represent a glaucoma predictor in an effort to improve glaucoma care.

Keywords: corneal hysteresis, $\mathrm{CH}$, corneal-compensated intraocular pressure, IOPcc, Goldmann-correlated intraocular pressure, IOPg, glaucoma, normative database, ocular biomechanics

\section{Introduction}

Causes of glaucoma apart from intraocular pressure-related optic nerve head damage were studied: for example, ocular microcirculation and perfusion impairment, lower cerebrospinal fluid pressure-related optic nerve damage, translaminar pressure gradient and ocular biomechanics-related optic neuropathy. ${ }^{1-6}$ The variation of the ocular biomechanical properties is highlighted as one of the potential optic nerve damage pathologies. This property may fill the gap of knowledge among cases with different disease progression despite similarity in other risk factors. ${ }^{7,8}$ 
Corneal hysteresis $(\mathrm{CH})$ is an easily measurable ocular biomechanical parameter. It refers to the property of corneal tissue absorbing and dispersing energy applied by a force. This dynamic property is shown as the cornea recoiling its shape. Measuring the corneal hysteresis is applicable and repeatable. Variation of corneal hysteresis is found among different races and ages. ${ }^{9-11}$ Detry-Morel et al reported lower $\mathrm{CH}$ in those of African descent compared with European descent. ${ }^{9}$ In younger European groups, Bueno-Gimeno et al found higher $\mathrm{CH}$ compared with older groups, ${ }^{10}$ similar to the result from Kamiya et al who studied those of Asian descent. ${ }^{11}$ Lower $\mathrm{CH}$ in glaucomatous eyes and keratoconic eyes than in normal eyes was also reported. ${ }^{12-14}$

This study aims at collecting the normal value data of corneal hysteresis and comparing corneal hysteresis between different glaucoma types and severity in Thai glaucoma patients.

\section{Materials and Methods}

This was a retrospective cross-sectional study of ocular hysteresis approved by the Mettapracharak (Wat Rai Khing) research ethics committee in accordance with the International Conference on Harmonization Good Clinical Practice (ICH-GCP) COA No 003/2563. Patients' consent to review their medical records was not required by the ethics committee. All privacy data including hospital number, name, and date of birth were masked and kept confidentially in compliance with the Declaration of Helsinki. The data of patients who visited the ophthalmology clinic and glaucoma clinic of Dr KR at Mettapracharak (Wat Rai Khing) hospital from January to March 2020 were included. Corneal hysteresis was measured by the Reichert ${ }^{\circledR}$ Ocular Response Analyzer ${ }^{\mathbb{B}} \mathrm{G} 3$, non-contact air puff tonometer. Three results were reported: ocular response analyzer parameters; corneal hysteresis $(\mathrm{CH})$, corneal-compensated intraocular pressure (IOPcc), and Goldmann-correlated intraocular pressure (IOPg). The data were excluded if the waveform score (WS) was below 3.5 suggesting too low reliability of the measurement. ${ }^{15,16}$

The inclusion criteria for normative data were the right eye or the only reliable eye of patients who presented with ocular diseases; for example, dry eye syndrome, refractive errors and senile cataracts whose visual acuity was better than 20/70, healthy optic nerve appearance and intraocular pressure below $22 \mathrm{mmHg}$. The exclusion criteria for normative data were glaucomatous optic neuropathy, glaucoma suspected optic disc, primary angle closure suspect, corneal pathology and post-refractive surgery eyes. In glaucomatous groups, data were collected from both eyes of patients. The inclusion criteria were primary open-angle glaucoma (POAG), primary close-angle glaucoma (PACG), ocular hypertension (OHT), and normal tension glaucoma (NTG). The exclusion criteria were corneal pathology and post-refractive surgery eyes. Demographic data from both groups were collected, for example, age, sex, type of glaucoma and severity staging of glaucoma classified by the visual field's mean deviation (MD) into early, moderate, and severe following Hodapp-ParrishAnderson glaucoma staging. ${ }^{17,18}$

\section{Statistical Analysis}

The data were analyzed by JASP 0.14.1. Descriptive statistics were applied to describe demographic data and results. Categorical data such as the differences of sexes between normal and glaucomatous groups, and within the glaucoma severity group, were tested by Chi-squared test, whereas continuous data such as age, method of treatment, and amount of anti-glaucoma medication were tested by one-way analysis of variance (ANOVA) and post hoc analysis by Bonferroni test. Differences of ocular response analyzer parameters in normative data between men and women were tested by Student's $t$-test. The Pearson correlation coefficient was applied to test the correlation of ocular response analyzer parameters between age and both eyes of the same person. The association between age and $\mathrm{CH}$ was tested by linear regression analysis. The generalized estimating equation (GEE) was applied to assess the difference of ocular response analyzer parameters and GAT between different types and severity of glaucoma. Statistical significance was set as $\mathrm{p}<0.05$.

\section{Results}

A total of 465 eyes from 465 normal participants met the inclusion criteria for the normative data of ocular response analyzer parameters (Table 1). Average age was $57.21 \pm$ 14.4 years, range between 14 and 87 years. Although women were predominantly included, mean ages between women and men were not different. Average $\mathrm{CH}$, IOPcc, and IOPg were $10.18 \pm 1.48 \mathrm{mmHg}, 15.01 \pm 3.04 \mathrm{mmHg}$, and $14.16 \pm 3.06 \mathrm{mmHg}$, respectively. The corneal hysteresis showed a normal distribution (Figure 1A), $\mathrm{CH}$ at the 2.5th and 5th percentile were 7.4 and $8.0 \mathrm{mmHg}$, respectively. The IOPcc and IOPg also showed a normal distribution (Figure 1B and C), IOPcc at the 97.5th and the 99th percentile were 21.00 and $22.1 \mathrm{mmHg}$, and $\mathrm{IOPg}$ at the 
Table I Demographic and Normative Data of Ocular Response Analyzer Parameters in Thais

\begin{tabular}{|c|c|c|c|}
\hline & $\begin{array}{l}\text { Women } \\
327 \text { Persons }\end{array}$ & $\begin{array}{l}\text { Men } \\
\text { I38 Persons }\end{array}$ & p value, $95 \% \mathrm{Cl}$ for Mean Difference \\
\hline $\begin{array}{l}\text { Eyes } \\
\text {-Right ( } 426 \text { eyes) } \\
\text {-Left ( } 421 \text { eyes) }\end{array}$ & \multicolumn{2}{|c|}{$\begin{array}{c}465 \text { Eyes } \\
426 \\
39\end{array}$} & \\
\hline \multirow[t]{2}{*}{ Age (years) } & \multicolumn{2}{|c|}{$57.21 \pm 14.43(14-87)$} & \\
\hline & $56.5 \mid \pm 14.92(\mid 4-87)$ & $58.88 \pm 13.09(26-85)$ & $p=0.16[-5.25,0.5]$ \\
\hline \multirow[t]{2}{*}{$\begin{array}{l}\text { Corneal hysteresis }(\mathrm{CH})(\mathrm{mmHg}) \\
-\mathrm{Ist}, 2.5 \text { th and } 5 \text { th percentile } \\
-95 \text { th, } 97.5 \text { th and } 99 \text { th percentile }\end{array}$} & \multicolumn{2}{|c|}{$\begin{array}{c}10.18 \pm 1.48(5.2-16.80) \\
6.7,7.40 \text { and } 8.0 \\
12.58,13.10 \text { and } 13.94\end{array}$} & \\
\hline & $10.29 \pm 1.46$ & $9.90 \pm 1.49$ & $\mathrm{p}=0.009[0.10,0.69]$ \\
\hline \multirow[t]{2}{*}{$\begin{array}{l}\text { Corneal-compensated intraocular } \\
\text { Pressure (IOPcc) (mmHg) } \\
-1 \text { st, } 2.5 \text { th and 5th percentile } \\
-95 \text { th, } 97.5 \text { th and 99th percentile }\end{array}$} & \multicolumn{2}{|c|}{$\begin{array}{c}15.01 \pm 3.04 \\
(6.50-23.10) \\
8.36,9.50,10.40 \\
20.08,21.00,22.1 \\
\end{array}$} & \\
\hline & $14.9 \pm 3.03$ & $15.27 \pm 3.04$ & $P=0.229[-0.98,0.23]$ \\
\hline \multirow[t]{2}{*}{$\begin{array}{l}\text { Goldmann-correlated intraocular } \\
\text { pressure }(\mathrm{IOPg})(\mathrm{mmHg}) \\
-1 \mathrm{st}, 2.5 \text { th and } 5 \text { th } \\
-95 \text { th, } 97.5 \text { th and 99th }\end{array}$} & \multicolumn{2}{|c|}{$\begin{array}{c}14.24 \pm 3.24 \\
(5.80-24.10) \\
6.73,7.70,8.60 \\
18.90,19.54,20.50\end{array}$} & \\
\hline & $14.18 \pm 3.08$ & $|4.1| \pm 3.00$ & $\mathrm{P}=0.827[-0.54,0.68]$ \\
\hline Waveform score (WS) & $6.6(1.78)$ & & \\
\hline
\end{tabular}

Note: Student's t-test.

97.5th and the 99th percentile were 19.54 and 20.50 $\mathrm{mmHg}$, respectively. Women had significantly higher $\mathrm{CH}$ than men at $10.29 \pm 1.46$ vs $9.90 \pm 1.49 \mathrm{mmHg}, \mathrm{p}=0.009$, $95 \%$ CI $[0.10,0.69]$ while IOPcc and IOPg between sexes were not different (Figure 2).

Moderate negative correlation was found between age and corneal hysteresis analyzed by Pearson's correlation coefficient $r=-0.338, \mathrm{p}<0.001,95 \%$ CI $[-0.416,-0.255]$ (Figure 3A). Meanwhile, the correlation between age and IOPcc $(r=0.110, \mathrm{p}=0.024,95 \%$ CI $[0.020,0.199])$ and age and IOPg $(r=-0.064, \mathrm{p}=0.139,95 \%$ CI $[-0.155,0.027])$ was not detected. Regression analysis between $\mathrm{CH}$ and age was $\mathrm{CH}=12.162-0.035$ (age). Ocular response analyzer parameters between eyes of the same person were similar $(\mathrm{CH}: r=0.667, \mathrm{p}<0.001$, IOPcc: $r=0.655$, $\mathrm{p}<0.001$. IOPg: $r=0.698, \mathrm{p}<0.001)$. Regression analysis between ocular response analyzer was IOPcc $=13.35+$ $0.86(\mathrm{IOPg})-1.02(\mathrm{CH})$. IOPcc and IOPg correlated highly positively, $r=0.835, \mathrm{p}<0.001$. IOPcc was significantly higher than IOPg, and the mean difference was $0.97 \mathrm{mmHg}, \mathrm{p}<0.001,95 \%$ CI $[0.854,1.086]$. IOPcc and
$\mathrm{CH}$ showed strong negative correlation, $r=-0.459$, $\mathrm{p}<0.0001,95 \%$ CI $[-0.510,-0.404]$ while IOPg and $\mathrm{CH}$ did not, $r=0.067, \mathrm{p}=0.057,95 \%$ CI $[-0.00,0.134]$ (Figure 3B).

There were 695 eyes from 429 patients including primary open-angle glaucoma (POAG) 434 eyes from 272 patients; primary close-angle glaucoma (PACG) 74 eyes from 48 patients; normal tension glaucoma (NTG) 143 eyes from 79 patients; ocular hypertension (OHT) 44 eyes from 30 patients. The OHT group was the youngest group, while the average ages between OAG, ACG, and NTG were similar. Following risk factors of specific glaucoma type, women were observed more frequently than men in the PACG and NTG groups. Glaucoma treatment options were also different between groups. All patients in the POAG and NTG groups received treatments and the most frequently prescribed anti-glaucoma medication was prostaglandin analogues. Phacoemulsification was performed in 29 of 74 eyes (39.2\%) of the PACG group. Average numbers of anti-glaucoma medications were between 1.12 and 1.36 . 


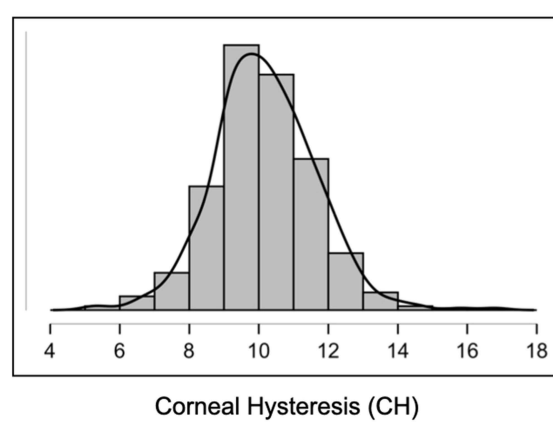

A

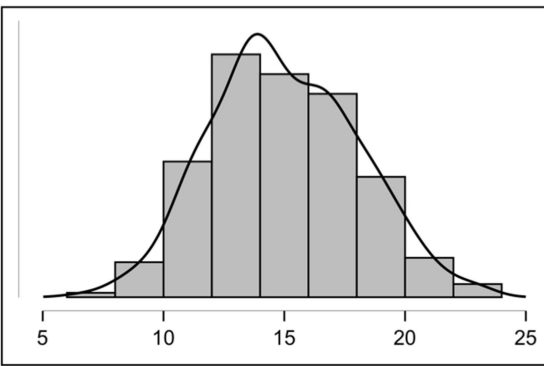

Corneal Compensated Intra-ocular Pressure (IOPcc)

B

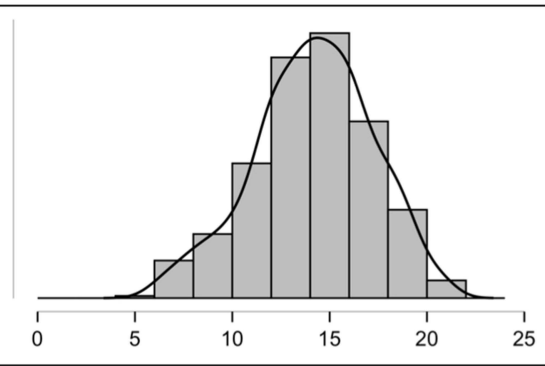

Goldmann Correlated Intraocular Pressure (IOPg)

Figure I Frequency distribution graph of ocular response analyzer parameters. (A) Frequency distribution graph of corneal hysteresis (CH). (B) Frequency distribution graph of corneal-compensated intraocular pressure (IOPcc). (C) Frequency distribution graph of Goldmann-correlated intraocular pressure (IOPg).

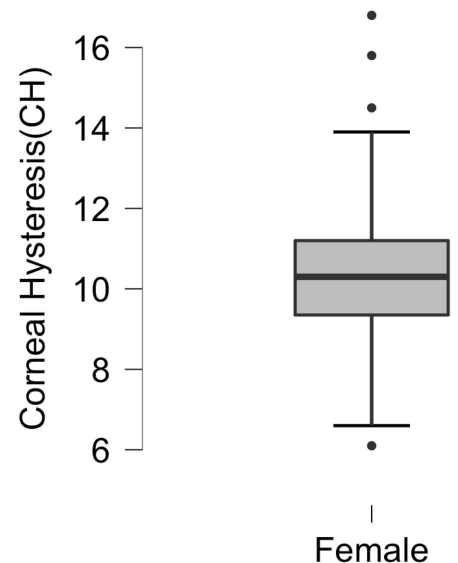

Sex

Figure 2 Box-plots of corneal hysteresis between women and men.

Following from Tables 2 and 3, the lowest $\mathrm{CH}$ was in the POAG group, $8.74 \pm 1.52 \mathrm{mmHg}$, followed by the PACG group, $9.09 \pm 1.72 \mathrm{mmHg}$, and the NTG group, $9.55 \pm 1.67 \mathrm{mmHg}$, while the highest was OHT, $10.10 \pm$ $1.40 \mathrm{mmHg}, \mathrm{p}<0.001$. Post hoc analysis comparing $\mathrm{CH}$ between glaucoma types was applied, and the mean $\mathrm{CH}$ of POAG was significantly lower than NTG and OHT $(\mathrm{p}<0.001)$. Mean $\mathrm{CH}$ of PACG was lower than OHT $(\mathrm{p}<0.001)$ while mean $\mathrm{CH}$ between $\mathrm{PACG}$ and POAG and between PACG and NTG were comparable, $\mathrm{p}=0.42$ and $\mathrm{p}=0.25$. The OHT group had the highest IOPg and IOPcc, while the lowest was NTG, p $<0.001$ which corresponded to the natural history of diseases.

The difference of $\mathrm{CH}$ between glaucoma severity was found to be negatively correlated with the more advanced glaucoma stage in the POAG and PACG groups. The average $\mathrm{CH}$ in early, moderate, and severe groups of POAG was $9.22 \pm 1.47,8.74 \pm 1.23$, and $7.92 \pm 1.40 \mathrm{mmHg}, \mathrm{p}<0.001$,

respectively. The average $\mathrm{CH}$ of PACG in the severe stage was significantly lower than in the early stage $(8.45 \pm 1.74$ vs $9.85 \pm 1.45 \mathrm{mmHg}, \mathrm{p}=0.004)$ and lower than the moderate stage $(9.04 \pm 1.68 \mathrm{mmHg}, \mathrm{p}=0.295)$ but this was statistically insignificant (Figure 4) Interestingly, among the NTG group, $\mathrm{CH}$ between different severity was not statistically different. Average IOPg, IOPcc, and GAT in the NTG group were the lowest compared with POAG and PACG (Table 4).

\section{Discussion}

Variation in ocular biomechanics is one of the possible glaucoma pathophysiologies. ${ }^{19}$ There have been studies of biomechanics in various parts of the eye, for example, cornea, sclera and lamina cribrosa of the optic nerve. Anterior scleral rigidity of glaucomatous eyes measured by Schiotz tonometer was lower than in normal eyes. ${ }^{20}$ The lowest ocular rigidity estimated by ocular pulse amplitude from pulsatile choroidal blood flow was for glaucomatous eyes when comparing between glaucoma eyes, normal, and ocular hypertension eyes. ${ }^{21}$ Lamina cribrosa of the optic nerve deformation was observed in glaucomatous eyes. ${ }^{22}$ Quantitative measurements of the ocular biomechanical properties of the sclera and the lamina cribrosa were developed in experimental studies but have not yet been applied in normal clinical practice. ${ }^{23}$

The quantifiable ocular biomechanical parameters in clinical-based practice were corneal properties, for example, corneal thickness and corneal hysteresis. The association between corneal thickness and glaucomatous risk development had been studied. Thinner corneal thickness groups had a higher risk of developing glaucoma in the case of ocular hypertension patients than the thicker 


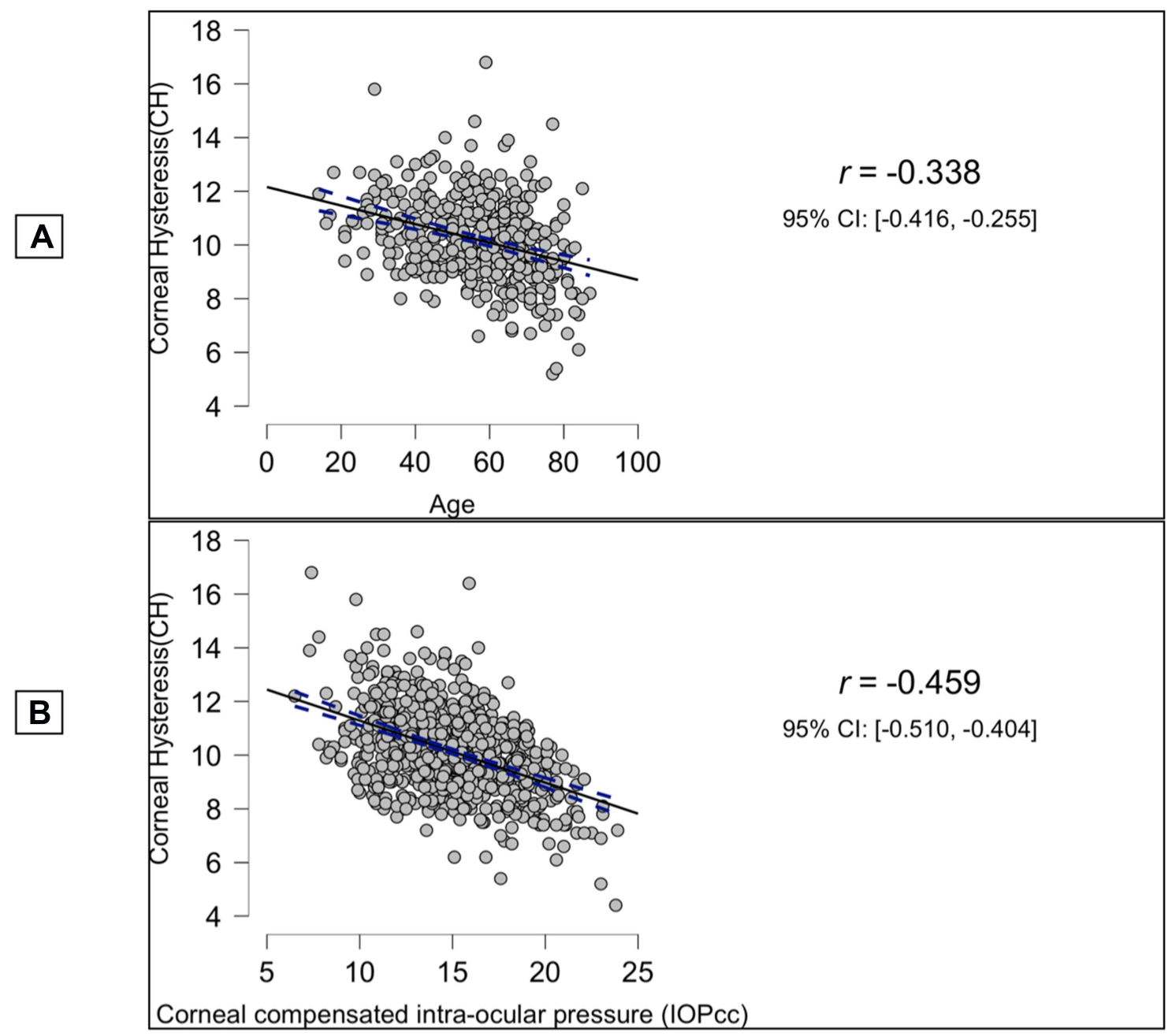

Figure 3 Scatter plot between ocular response analyzer parameters. (A) Scatter plot between corneal hysteresis (CH) and age. (B) Scatter plots between cornealcompensated intraocular pressure $(\mathrm{IOPcc})$ and corneal hysteresis $(\mathrm{CH})$.

groups. ${ }^{24,25}$ Furthermore, actual intraocular pressure measurement was confounded by central corneal thickness as out-of-range central corneal thickness was associated with under or overestimated IOP. ${ }^{26,27}$ Ocular response analyzer, a non-contact air puff tonometer and ocular hysteresis measuring device, is widely used in ophthalmology and optometry clinics. Corneal hysteresis refers to a dynamic property of the cornea, which performs as shock absorbance and is inversely associated with intraocular pressure. High reliability and high reproducibility of this device could be observed. ${ }^{15,16,28}$ Normative databases of corneal hysteresis had been studied internationally, and the results varied narrowly among different ethnicities as shown in Table 5. Caucasians in the younger age group had higher $\mathrm{CH}$ than in older groups $(12.12 \mathrm{mmHg}$ vs 10.00 to $10.44 \mathrm{mmHg})^{10,29-31}$ while the lowest $\mathrm{CH}$ was in those of African descent, at 9.2 to $9.70 \mathrm{mmHg} .{ }^{9,32} \mathrm{CH}$ in Asian and Middle Eastern groups were comparable, while the younger ages had higher $\mathrm{CH}$ similar to Caucasians (10.7 to $11.78 \mathrm{mmHg}$ vs 10.1 to 10.25 $\mathrm{mmHg}){ }^{33-38}$ Our results were similar to other Asians. Our proposed regression model equations between age and $\mathrm{CH}$ revealed that increasing age showed negative correlation with $\mathrm{CH}$, corresponding to the findings of Foster et al, as $\mathrm{CH}$ decreased by $0.34 \mathrm{mmHg}$ per decade. $^{31}$ Age-related ocular biomechanical property degeneration associated with glaucoma was observed in cornea, trabecular meshwork, and lamina cribrosa. ${ }^{39-42}$ For instance, a decrease in collagen would enhance compliance at the lamina cribrosa that worsens the health of the optic nerve head and leads to retinal ganglion cell death. Aging affected the stiffness of corneal tissue from the alteration of the corneal structural composition: collagen fibers, glycosaminoglycans, and proteoglycans. $\mathrm{CH}$ 
Table 2 Demographic Data and Ocular Response Analyzer Parameters in Different Glaucoma Type

\begin{tabular}{|c|c|c|c|c|c|}
\hline & $\begin{array}{l}\text { Primary Open-Angle } \\
\text { Glaucoma (POAG) }\end{array}$ & $\begin{array}{l}\text { Primary Close-Angle } \\
\text { Glaucoma (PACG) }\end{array}$ & $\begin{array}{l}\text { Normal Tension } \\
\text { Glaucoma (NTG) }\end{array}$ & $\begin{array}{l}\text { Ocular } \\
\text { Hypertension } \\
\text { (OHT) }\end{array}$ & p-value ${ }^{\#}$ \\
\hline $\begin{array}{l}\text { Number of eyes/ Number of } \\
\text { patients }\end{array}$ & 434 Eyes/272 patients & 74 Eyes/48 patients & $\begin{array}{l}\text { I43 Eyes/ } 79 \\
\text { patients }\end{array}$ & $\begin{array}{l}44 \text { Eyes/30 } \\
\text { patients }\end{array}$ & \\
\hline Male & 177 & 11 & 25 & 16 & $<0.00 \mathrm{I}^{\mathrm{abe}}$ \\
\hline Female & 95 & 37 & 54 & 14 & \\
\hline Age (years) & $68.07 \pm 10.04$ & $68.48 \pm 10.43$ & $65.88 \pm 11.66$ & $59.39 \pm 9.78$ & $0.002^{\text {cef }}$ \\
\hline Treatment & & & & & $<0.001^{\mathrm{ac}}$ \\
\hline -Medication & 421 & 45 & 143 & 24 & \\
\hline -Selective laser trabeculoplasty & 8 & - & - & - & \\
\hline -Trabeculectomy & 5 & - & - & - & \\
\hline -Phacoemulsification & - & 29 & - & - & \\
\hline Anti-glaucoma medication (No.) & $1.36 \pm 0.5$ & $1.32 \pm 0.5$ & $1.12 \pm 0.4$ & $1.2 \pm 0.4$ & $<0.001^{b}$ \\
\hline -Prostaglandin analogues & 414 & 46 & $|4|$ & 24 & \\
\hline -Carbonic anhydrase inhibitors & 67 & - & 7 & 2 & \\
\hline -Alpha agonist & 4 & - & - & - & \\
\hline -Beta blockers & 89 & 16 & 12 & 3 & \\
\hline Corneal hysteresis $(\mathrm{CH}) \mathrm{mmHg}$ & $8.74 \pm 1.52$ & $9.09 \pm 1.72$ & $9.55 \pm 1.67$ & $10.10 \pm 1.40$ & $<0.001^{\text {bce }}$ \\
\hline $\begin{array}{l}\text { Corneal-compensated } \\
\text { intraocular pressure (IOPcc) } \\
\mathrm{mmHg}\end{array}$ & $17.19 \pm 4.62$ & $16.65 \pm 4.28$ & $13.94 \pm 2.82$ & $19.92 \pm 4.95$ & $<0.001^{\text {bcdef }}$ \\
\hline $\begin{array}{l}\text { Goldmann-correlated } \\
\text { intraocular pressure (IOPg) } \\
\mathrm{mmHg}\end{array}$ & $14.82 \pm 4.73$ & $14.62 \pm 4.32$ & $12.30 \pm 2.93$ & $19.75 \pm 4.83$ & $<0.00 \mathrm{I}^{\text {bcdef }}$ \\
\hline Waveform score (WS) & $6.88 \pm 1.79$ & $6.85 \pm 1.89$ & $6.35 \pm 1.89$ & $6.64 \pm 1.61$ & 0.361 \\
\hline $\begin{array}{l}\text { Goldmann applanation } \\
\text { tonometry (GAT) } \mathrm{mmHg}\end{array}$ & $15.15 \pm 4.32$ & $15.30 \pm 3.95$ & $12.70 \pm 2.78$ & $19.51 \pm 3.14$ & $<0.001^{b}$ \\
\hline
\end{tabular}

Notes: ${ }^{\#}$ One-way ANOVA for continuous data and chi-square test for categorical data. ${ }^{\#}$ Generalized estimating equation (GEE) for ocular response analyzer parameters. ${ }^{a}$ Significant difference between OAG and ACG, 'bignificant difference between OAG and NTG, 'Significant difference between OAG and OTH, ${ }^{\mathrm{d}}$ Significant difference between ACG and NTG, ${ }^{\mathrm{S}}$ Significant difference between ACG and OTH, '́ Significant difference between NTG and OTH.

of women in our study was significantly higher than in men similar to the results from other studies. $^{31,39}$ However, the average ages of women and men in this study were approximately $56.51 \pm 14.92$ vs $58.88 \pm$ 13.09 years, $p=0.16$. Apart from aging, the estrogen hormone plays an important role in ocular biomechanical changes. Estrogen receptors presented in many ocular tissues and are associated with the growth of collagen fiber which affects corneal hysteresis as well as neuroprotection in glaucoma pathophysiology. ${ }^{43,44}$

Several studies had tried to apply $\mathrm{CH}$ as a predictor of developing glaucoma and a predictor of glaucoma progression. Schweitzer et al found moderate and severe glaucoma were 2.9 times more likely to have $\mathrm{CH}$ below
$10 \mathrm{mmHg}$, which was similar to the finding from Park et al, in which $67 \%$ risk of progression was found in eyes with $\mathrm{CH}$ below $10.1 \mathrm{mmHg} .{ }^{45,46}$ Following the normal distribution plot of $\mathrm{CH}$, the low percentiles of $\mathrm{CH}$ normative data could be applied as the deviation value (lower than average) from normal, for example $\mathrm{CH}$ at the 5th percentile was $8.0 \mathrm{mmHg}$, which was lower than $95 \%$ of normal and $\mathrm{CH}$ at the 1st percentile was $6.7 \mathrm{mmHg}$., which was lower than $99 \%$ of normal. This value could be a potential cut-off point of discrimination between normal and deviations from normal (lower than average) $\mathrm{CH}$ in Thais.

Among IOPcc, IOPg, and GAT, exactly which value would be the best to represent the true IOP is still under 
Table 3 Post Hoc Comparisons of Corneal Hysteresis (CH), Corneal-Compensated Intraocular Pressure (IOPcc) and GoldmannCorrelated Intraocular Pressure (IOPg) Between Primary Open-Angle Glaucoma (POAG), Primary Close-Angle Glaucoma (PACG), Normal Tension Glaucoma (NTG) and Ocular Hypertension (OHT)

\begin{tabular}{|c|c|c|c|c|c|c|c|}
\hline \multicolumn{8}{|c|}{ Corneal Hysteresis (CH) } \\
\hline & & & \multicolumn{2}{|c|}{ 95\% $\mathrm{Cl}$ for Mean Difference } & \multirow[b]{2}{*}{ SE } & \multirow[b]{2}{*}{$t$} & \multirow[b]{2}{*}{ p bonf } \\
\hline & & Mean Difference & Lower & Upper & & & \\
\hline \multirow[t]{3}{*}{ POAG } & PACG & -0.359 & -0.867 & 0.149 & 0.197 & -1.820 & 0.415 \\
\hline & NTG & -0.815 & -1.202 & -0.427 & 0.150 & -5.416 & $<0.001$ \\
\hline & OHT & -1.367 & -2.006 & -0.728 & 0.248 & -5.511 & $<0.001$ \\
\hline \multirow[t]{2}{*}{ PACG } & NTG & -0.456 & -1.032 & 0.121 & 0.224 & -2.035 & 0.253 \\
\hline & $\mathrm{OHT}$ & -1.008 & -1.777 & -0.240 & 0.298 & -3.378 & 0.005 \\
\hline NTG & $\mathrm{OHT}$ & -0.552 & -1.247 & 0.142 & 0.270 & -2.047 & 0.246 \\
\hline
\end{tabular}

Corneal-Compensated Intraocular Pressure (IOPcc)

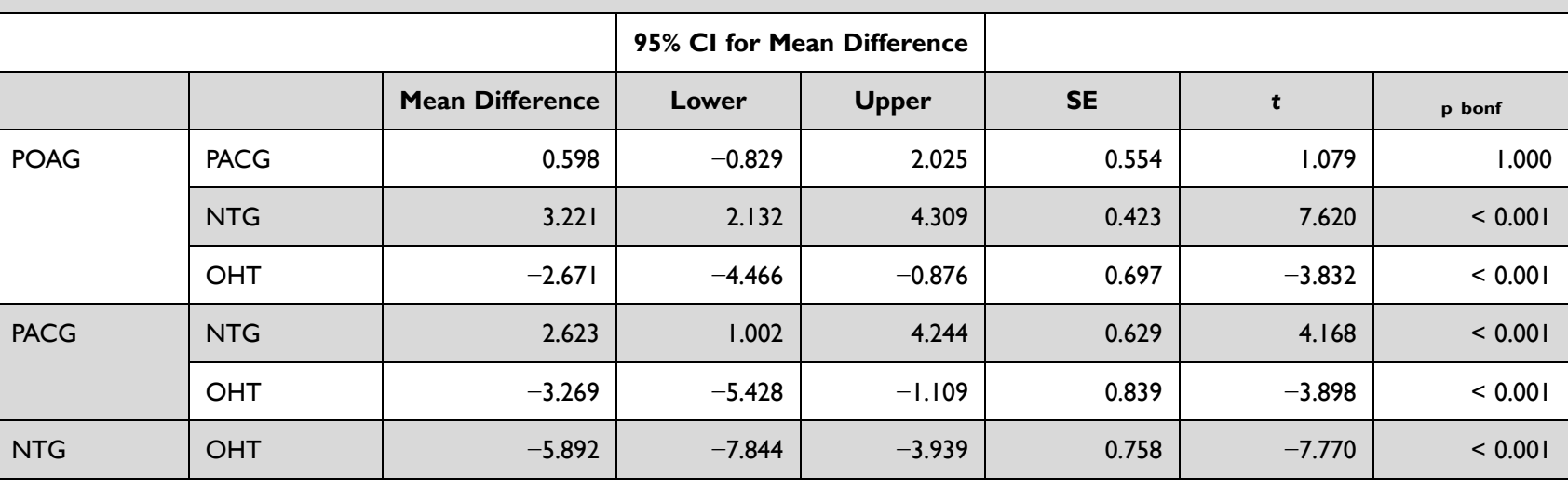

Goldmann-Correlated Intraocular Pressure (IOPg)

\begin{tabular}{|c|c|c|c|c|c|c|c|}
\hline & & & \multicolumn{2}{|c|}{ 95\% Cl for Mean Difference } & \multirow[b]{2}{*}{ SE } & \multirow[b]{2}{*}{$\boldsymbol{t}$} & \multirow[b]{2}{*}{ p bonf } \\
\hline & & Mean Difference & Lower & Upper & & & \\
\hline \multirow[t]{3}{*}{ POAG } & PACG & 0.158 & -1.261 & 1.577 & 0.551 & 0.287 & 1.000 \\
\hline & NTG & 2.539 & 1.457 & 3.622 & 0.420 & 6.041 & $<0.001$ \\
\hline & OHT & -4.913 & -6.698 & -3.128 & 0.693 & -7.089 & $<0.001$ \\
\hline \multirow[t]{2}{*}{ PACG } & NTG & 2.381 & 0.770 & 3.993 & 0.626 & 3.806 & $<0.001$ \\
\hline & OHT & $-5.07 \mid$ & -7.218 & -2.924 & 0.834 & -6.082 & $<0.001$ \\
\hline NTG & OHT & -7.452 & -9.394 & -5.511 & 0.754 & -9.886 & $<0.001$ \\
\hline
\end{tabular}

Notes: P-value and confidence intervals adjusted for comparing a family of four estimates (confidence intervals corrected using the turnkey method).

debate. ${ }^{47-49}$ The gold standard of IOP measuring is the GAT, whose accuracy is limited when applied in out-ofthe range central corneal thickness (CCT), for example, in post-refractive surgery and thinner or thicker than normal average CCT. IOPcc is less affected by corneal properties as a CCT independent IOP measurement. ${ }^{49}$ Ehrlich et al showed better sensitivity and specificity to identify glaucoma using IOPcc compared with GAT. Applying an optimal GAT threshold at $20.9 \mathrm{mmHg}$, GAT showed area under curve $(\mathrm{AUC})=0.78$, while 


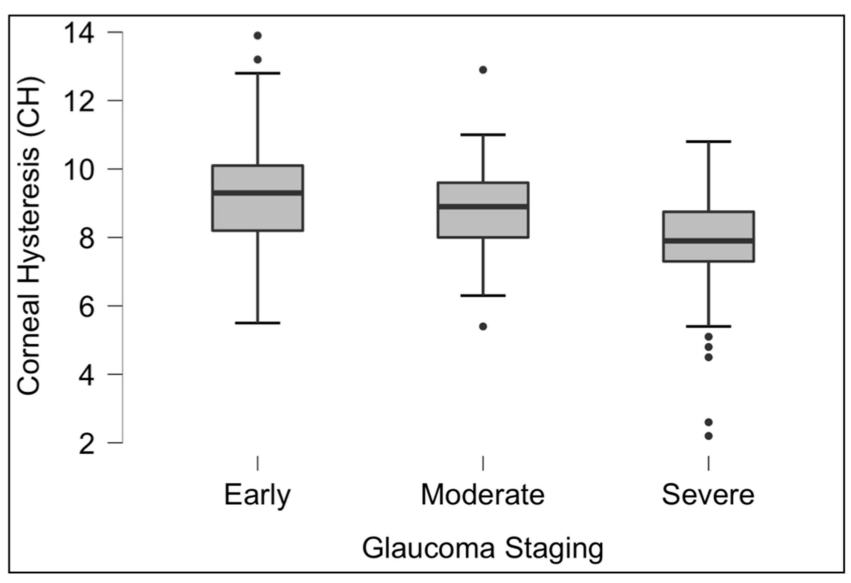

A

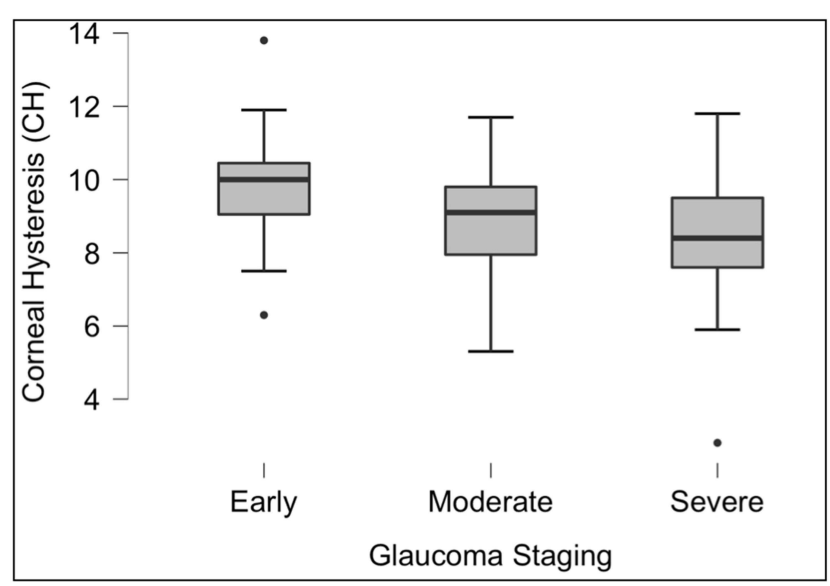

B

Figure 4 Box-plot of corneal hysteresis of primary open-angle glaucoma (POAG) and primary close-angle glaucoma (PACG) in different glaucoma severity. (A) Primary open-angle glaucoma (POAG). (B) Primary close-angle glaucoma (PACG).

using an IOPcc threshold at $18.4 \mathrm{mmHg}$, IOPcc showed AUC $=0.93, p<0.001 .^{50}$

Our data for IOPcc were significantly higher than IOPg, $15.01 \pm 3.04$ vs. $14.24 \pm 3.24 \mathrm{mmHg}, \mathrm{p}<0.001$. This value was also higher than the normative data study of GAT by Bourne et al at $13.3 \pm 3.2 \mathrm{mmHg} .{ }^{51}$ Compared with other ethnic groups, IOP was similar to other Asians but lower than Caucasians. ${ }^{51-53}$ We could apply the 97.5 th percentile of IOPcc $(20.08 \mathrm{mmHg})$ and IOPg $(19.54 \mathrm{mmHg})$ as the proper cut-off point IOP for glaucoma diagnosis, which is more accurate than the traditional criteria. ${ }^{54}$

Corneal hysteresis had been studied as a predictor for glaucoma progression. For example, each $1 \mathrm{mmHg}$ lower $\mathrm{CH}$ was associated with a $21 \%$ increase in the risk of developing glaucoma in the glaucoma suspected group (95\% CI [1.04-1.41], $\mathrm{P}=0.013$ ). Each $1 \mathrm{mmHg}$ lower $\mathrm{CH}$ was associated with a faster rate of deterioration of the retinal nerve fiber layer (RNFL), $0.13 \mu \mathrm{m} /$ year faster, and each $1 \mathrm{mmHg}$ lower $\mathrm{CH}$ was associated with a $0.25 \% /$ year faster rate of visual field index (VFI) decline over time (P $<0.001) .{ }^{55-58}$

Our results of $\mathrm{CH}$ in different glaucoma types were comparable with previous studies that reported corresponding $\mathrm{CH}$ between PACG and POAG, while average $\mathrm{CH}$ of NTG was higher than both POAG and PACG (POAG 9.0-10.03 mmHg, PACG 9.1 $\mathrm{mmHg}$, and NTG 9.6-9.88mmHg). ${ }^{9,12,59-61}$ When comparing between severity levels of glaucoma, our findings were similar to others in that the more advanced stages of glaucoma correlated with lower $\mathrm{CH}^{13}$
One limitation of our study was that the average $\mathrm{CH}$ in glaucoma might not represent the original $\mathrm{CH}$, because all patients' IOP were already controlled with anti-glaucoma treatment.

Several studies showed the relationship between IOP and $\mathrm{CH}$; lowering IOP can increase $\mathrm{CH}$, and likewise increasing IOP is associated with lowering $\mathrm{CH}$. Increasing $\mathrm{CH}$ can be both directly and indirectly caused by topical prostaglandin analogues. Firstly, topical prostaglandin analogues alter the structure of the cornea at the level of the extracellular matrix by increasing keratocyte density in corneal stroma. ${ }^{62}$ Secondly, topical prostaglandin analogues as well as any anti-glaucoma treatment indirectly increase $\mathrm{CH}$ as a result of decreasing IOP. ${ }^{63,64}$

The second limitation was a retrospective crosssectional study design with lack of data to compare in the long term. The third limitation was the generalizability of the corneal hysteresis parameter results as the reference value. Our future development plan was to include more participants of various age groups to generate a normative database for the Thai population.

\section{Conclusion}

Corneal hysteresis is a reliable and repeatable value of ocular biomechanics that can be measured in clinical practice. The more advanced glaucoma stage in POAG and PACG had the lower $\mathrm{CH}$. Compared with the normal value data, low percentiles of $\mathrm{CH}$ can be set as a cut-off point of discrimination between normal 
Table 4 Demographic Data and Ocular Response Analyzer Parameters in Different Glaucoma Severity

\begin{tabular}{|c|c|c|c|c|}
\hline & $\begin{array}{l}\text { Primary Open-Angle } \\
\text { Glaucoma (POAG) }\end{array}$ & $\begin{array}{l}\text { Primary Close-Angle } \\
\text { Glaucoma (PACG) }\end{array}$ & $\begin{array}{l}\text { Normal Tension } \\
\text { Glaucoma (NTG) }\end{array}$ & p-value ${ }^{\#}$ \\
\hline $\begin{array}{l}\text { Glaucoma Stage } \\
\text {-Early } \\
\text {-Moderate } \\
\text {-Severe }\end{array}$ & $\begin{array}{l}225(51.85 \%) \\
74(17.05 \%) \\
135(31.10 \%)\end{array}$ & $\begin{array}{l}27(36.48 \%) \\
14(18.92 \%) \\
33(44.60 \%)\end{array}$ & $\begin{array}{l}91(63.64 \%) \\
32(22.38 \%) \\
20(13.98 \%)\end{array}$ & $\begin{array}{l}1.00 \\
0.049^{\mathrm{a}} \\
<0.001^{\mathrm{a}}\end{array}$ \\
\hline $\begin{array}{l}\text { Age (years) } \\
\text {-Early } \\
\text {-Moderate } \\
\text {-Severe }\end{array}$ & $\begin{array}{l}68.07 \pm 10.04 \\
65.75 \pm 9.89 \\
68.76 \pm 9.90 \\
71.23 \pm 9.50\end{array}$ & $\begin{array}{l}68.48 \pm 10.43 \\
68.78 \pm 8.64 \\
71.13 \pm 4.85 \\
65.95 \pm 12.52\end{array}$ & $\begin{array}{l}65.88 \pm 11.66 \\
62.27 \pm 11.02 \\
71.81 \pm 10.09 \\
77.60 \pm 7.96\end{array}$ & $\begin{array}{l}0.38 \\
0.188 \\
0.188 \\
0.189\end{array}$ \\
\hline $\begin{array}{l}\text { Corneal hysteresis }(\mathrm{CH}) \mathrm{mmHg} \\
\text {-Early } \\
\text {-Moderate } \\
\text {-Severe } \\
\text { p-value }\end{array}$ & $\begin{array}{l}8.74 \pm 1.52 \\
9.22 \pm 1.47 \\
8.74 \pm 1.23 \\
7.92 \pm 1.40 \\
<0.001^{\text {de }}\end{array}$ & $\begin{array}{l}9.09 \pm 1.72 \\
9.85 \pm 1.45 \\
9.04 \pm 1.68 \\
8.45 \pm 1.74 \\
0.004^{\mathrm{de}}\end{array}$ & $\begin{array}{l}9.55 \pm 1.67 \\
9.47 \pm 1.38 \\
9.75 \pm 2.42 \\
9.77 \pm 1.34 \\
0.525\end{array}$ & $\begin{array}{l}<0.00 \mathrm{I}^{\mathrm{a}} \\
0.055 \\
0.095 \\
<0.00 \mathrm{I}^{\mathrm{a}}\end{array}$ \\
\hline $\begin{array}{l}\text { Corneal-compensated intraocular } \\
\text { pressure (IOPcc) } \mathrm{mmHg} \\
\text {-Early } \\
\text {-Moderate } \\
\text {-Severe } \\
\text { p-value }^{\#}\end{array}$ & $\begin{array}{l}17.19 \pm 4.62 \\
16.58 \pm 4.07 \\
16.77 \pm 3.89 \\
18.61 \pm 5.90 \\
0.001^{\mathrm{de}}\end{array}$ & $\begin{array}{l}16.65 \pm 4.28 \\
16.38 \pm 4.42 \\
16.86 \pm 2.94 \\
16.73 \pm 4.70 \\
0.910\end{array}$ & $\begin{array}{l}13.94 \pm 2.82 \\
14.15 \pm 2.67 \\
13.21 \pm 3.27 \\
14.05 \pm 2.76 \\
0.379\end{array}$ & $\begin{array}{l}<0.001^{\mathrm{ab}} \\
<0.001^{\mathrm{ab}} \\
<0.001^{\mathrm{ab}} \\
<0.001^{\mathrm{ab}}\end{array}$ \\
\hline $\begin{array}{l}\text { Goldmann-correlated intraocular } \\
\text { pressure (IOPg), } \mathrm{mmHg} \\
\text {-Early } \\
\text {-Moderate } \\
\text {-Severe } \\
\text { p-value }\end{array}$ & $\begin{array}{l}14.82 \pm 4.73 \\
14.63 \pm 4.09 \\
14.27 \pm 4.22 \\
15.46 \pm 5.88 \\
0.24 \mid\end{array}$ & $\begin{array}{l}14.64 \pm 4.37 \\
15.27 \pm 4.47 \\
14.8 \mid \pm 3.70 \\
14.05 \pm 4.60 \\
0.565\end{array}$ & $\begin{array}{l}12.30 \pm 2.93 \\
12.41 \pm 3.14 \\
11.75 \pm 2.30 \\
12.57 \pm 2.79 \\
0.399\end{array}$ & $\begin{array}{l}<0.001^{\mathrm{ab}} \\
<0.00 \mathrm{I}^{\mathrm{ab}} \\
<0.00 \mathrm{I}^{\mathrm{ab}} \\
0.002^{\mathrm{a}}\end{array}$ \\
\hline $\begin{array}{l}\text { Goldmann applanation tonometry } \\
\text { (GAT), } \mathrm{mmHg} \\
\text {-Early } \\
\text {-Moderate } \\
\text {-Severe } \\
\text { p-value } \#\end{array}$ & $\begin{array}{l}15.15 \pm 4.32 \\
14.54 \pm 3.72 \\
15.25 \pm 4.14 \\
16.11 \pm 5.29 \\
0.023 d\end{array}$ & $\begin{array}{l}15.30 \pm 3.95 \\
15.90 \pm 3.93 \\
15.33 \pm 3.75 \\
14.83 \pm 4.25 \\
0.678\end{array}$ & $\begin{array}{l}12.70 \pm 2.78 \\
12.79 \pm 2.79 \\
12.55 \pm 2.14 \\
12.50 \pm 3.65 \\
0.898\end{array}$ & $\begin{array}{l}<0.00 \mathrm{I}^{\mathrm{ab}} \\
<0.00 \mathrm{I}^{\mathrm{ab}} \\
<0.00 \mathrm{I}^{\mathrm{ab}} \\
0.003^{\mathrm{a}}\end{array}$ \\
\hline
\end{tabular}

Notes: \#One-way ANOVA for continuous data and chi-square test for categorical data. ${ }^{\text {\#} G e n e r a l i z e d ~ e s t i m a t i n g ~ e q u a t i o n ~(G E E) ~ f o r ~ o c u l a r ~ r e s p o n s e ~ a n a l y z e r ~ p a r a m e t e r s . ~}$ ${ }^{a}$ Significant difference between OAG and NTG, bSignificant difference between ACG and NTG, 'Significant difference between early and moderate stage, 'Significant

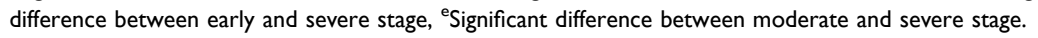

and deviations from normal. Following from its dynamic property, $\mathrm{CH}$ could serve as a glaucoma predictor to improve glaucoma care, for example, following the response to treatment, and identifying risk or predictive values for developing glaucoma in suspected groups. 
Table 5 Corneal Hysteresis $(\mathrm{CH})$ in Different Ethnics

\begin{tabular}{|c|c|c|c|}
\hline Ethnics and Authors & Number & $\begin{array}{l}\text { Corneal Hysteresis } \\
(\mathrm{CH})\end{array}$ & Age (Years) \\
\hline $\begin{array}{l}\text { Caucasian, Spain } \\
\text { Bueno-Gimeno et al }{ }^{10}\end{array}$ & $\begin{array}{l}293 \text { Eyes } \\
293 \text { Participants }\end{array}$ & $12.12 \pm 1.71 \mathrm{~mm} \mathrm{Hg}$ & $6-17$ years \\
\hline $\begin{array}{l}\text { Caucasian, London, United Kingdom } \\
\text { Carbonaro et } \mathrm{al}^{29}\end{array}$ & 264 Eyes from twin pairs & $10.24 \pm 1.54 \mathrm{~mm} \mathrm{Hg}$ & $54.1(16-78)$ \\
\hline $\begin{array}{l}\text { Caucasian, Birmingham, United } \\
\text { Kingdom } \\
\text { Shah et } \mathrm{al}^{30}\end{array}$ & $\begin{array}{l}207 \text { Eyes } \\
105 \text { Participants }\end{array}$ & $\begin{array}{l}10.7 \pm 2.0 \mathrm{~mm} \mathrm{Hg}(6.1- \\
17.6)\end{array}$ & $\begin{array}{l}62.1 \pm 18.1(18.1- \\
87.1)\end{array}$ \\
\hline $\begin{array}{l}\text { Caucasian, United Kingdom } \\
\text { Foster et } \mathrm{al}^{31}\end{array}$ & $4 \mid 84$ Participants & $\begin{array}{l}10.00 \pm 1.64 \mathrm{mmHg} \\
\text { Women } 10.18 \pm 1.58 \mathrm{mmHg} \\
\text { Men } 9.79 \pm 1.69 \mathrm{mmHg}, P< \\
0.001\end{array}$ & $48-91$ \\
\hline $\begin{array}{l}\text { African and Caucasians, Brussels } \\
\text { Detry-Morel et al }{ }^{9}\end{array}$ & $\begin{array}{l}30 \text { African } \\
25 \text { Caucasians }\end{array}$ & $\begin{array}{l}9.2 \pm 1.5 \mathrm{mmHg} \\
10.8 \pm 1.6 \mathrm{mmHg}\end{array}$ & $\begin{array}{l}43.9 \pm 11.4 \\
58.4 \pm 14.7\end{array}$ \\
\hline $\begin{array}{l}\text { African and Caucasians, San Diego, } \\
\text { USA } \\
\text { Leite et } \mathrm{al}^{32}\end{array}$ & $\begin{array}{l}46 \text { Eyes/ } 37 \text { blacks } \\
135 \text { Eyes/ } 82 \text { whites }\end{array}$ & $\begin{array}{l}9.70 \pm 1.72 \mathrm{mmHg} \\
10.44 \pm 1.6 \mathrm{mmHg}\end{array}$ & $\begin{array}{l}58.41 \pm 15.7 \\
66.00 \pm 11.9\end{array}$ \\
\hline $\begin{array}{l}\text { Middle easterner, Iran } \\
\text { Sedaghat et } \mathrm{al}^{33}\end{array}$ & $\begin{array}{l}506 \text { Eyes } \\
253 \text { Participants }\end{array}$ & $10.07 \pm 1.61 \mathrm{~mm} \mathrm{Hg}$ & $28.43 \pm 6.36(18-35)$ \\
\hline $\begin{array}{l}\text { Middle easterner, Egypt } \\
\mathrm{Ali}^{34}\end{array}$ & $\begin{array}{l}194 \text { Eyes } \\
98 \text { Participants }\end{array}$ & $\begin{array}{l}10.25 \pm 0.12 \mathrm{mmHg}(6.5- \\
14.4) \\
11.1 \pm 0.14 \mathrm{mmHg} \\
9.8 \pm 0.21 \mathrm{mmHg}\end{array}$ & $\begin{array}{l}45 \text { years } \\
\text { Younger age (19-40 } \\
\text { years) } \\
\text { Older age (40-71 } \\
\text { years) }\end{array}$ \\
\hline $\begin{array}{l}\text { Asian, Singapore } \\
\text { Lim et } \text { al }^{35}\end{array}$ & $\begin{array}{l}27 I \text { Eyes from I } 86 \text { Chinese, } 50 \text { Malay, } 33 \text { Indian, } \\
\text { and } 2 \text { other }\end{array}$ & $\begin{array}{l}\mathrm{I} 1.78 \pm 1.55 \mathrm{mmHg}(6.93- \\
\mathrm{I} 6.53)\end{array}$ & $13.97 \pm 0.89$ \\
\hline $\begin{array}{l}\text { Asian, rural Chinese secondary school } \\
\text { children. } \\
\text { Song et } \mathrm{al}^{36}\end{array}$ & 1233 Eyes from 1293 participants & $10.7 \pm 1.6 \mathrm{mmHg}$ & $14.7 \pm 0.8$ \\
\hline $\begin{array}{l}\text { Asian, Seoul, Korea } \\
\text { Hwang et } \mathrm{al}^{37}\end{array}$ & 958 Eyes from 958 patients & $10.1 \pm 1.4 \mathrm{mmHg}(7.1-17.2)$ & 26.7 \\
\hline $\begin{array}{l}\text { Asian, Taipei, Taiwan } \\
\text { Wang el } \mathrm{al}^{38}\end{array}$ & 292 Healthy eyes/ 292 person & $10.16 \pm 1.55 \mathrm{mmHg}(8-14)$ & $\begin{array}{l}66.51 \pm 12.12(33- \\
87)\end{array}$ \\
\hline This study & 465 Eyes from 465 participants & $\begin{array}{l}10.18 \pm 1.48 \mathrm{mmHg}(5.2 \text { to } \\
\text { 16.80) } \\
\text { Women } 10.29 \pm 1.46 \\
\mathrm{mmHg} \\
\text { Men } 9.90 \pm 1.49 \mathrm{mmHg} \\
\mathrm{p}=0.009\end{array}$ & $\begin{array}{l}57.21 \pm 14.43(14- \\
87)\end{array}$ \\
\hline
\end{tabular}




\section{Abbreviations}

$\mathrm{CH}$, corneal hysteresis; IOPcc, corneal-compensated intraocular pressure; GAT, Goldmann application tonometry; POAG, primary open-angle glaucoma; PACG, primary close-angle glaucoma; NTG, normal tension glaucoma; OHT, ocular hypertension; WS, waveform score.

\section{Acknowledgments}

Thanks to Dr Puwat Charukamnoetkanok for proofreading this article.

\section{Disclosure}

The author reports no conflicts of interest in this work.

\section{References}

1. Leske MC. Ocular perfusion pressure and glaucoma: clinical trial and epidemiologic findings. Curr Opin Ophthalmol. 2009;20(2):73-78. doi:10.1097/ICU.0b013e32831 eef82

2. Girard MJ, Dupps WJ, Baskaran M, et al. Translating ocular biomechanics into clinical practice: current state and future prospects. Curr Eye Res. 2015;40(1):1-18. doi:10.3109/02713683.2014.914543

3. Nguyen TD, Ethier CR. Biomechanical assessment in models of glaucomatous optic neuropathy. Exp Eye Res. 2015;141:125-138. doi:10.1016/j.exer.2015.05.024

4. Siaudvytyte L, Januleviciene I, Ragauskas A, et al. The difference in translaminar pressure gradient and neuroretinal rim area in glaucoma and healthy subjects. J Ophthalmol. 2014;2014:937360. doi:10.1155/ 2014/937360

5. Jonas JB, Ritch R, Panda-Jonas S. Cerebrospinal fluid pressure in the pathogenesis of glaucoma. Prog Brain Res. 2015;221:33-47. doi:10.1016/bs.pbr.2015.06.002

6. Ren R, Jonas JB, Tian G, et al. Cerebrospinal fluid pressure in glaucoma: a prospective study. Ophthalmology. 2010;117 (2):259-266. doi:10.1016/j.ophtha.2009.06.058

7. Dascalescu D, Corbu C, Constantin M, et al. Correlations between corneal biomechanics and glaucoma severity in patients with primary open angle glaucoma. Maedica (Bucur). 2015;10(4):331-335.

8. Liang L, Zhang R, He LY. Corneal hysteresis and glaucoma. Int Ophthalmol. 2019;39(8):1909-1916. doi:10.1007/s10792-0181011-2

9. Detry-Morel M, Jamart J, Hautenauven F, Pourjavan S. Comparison of the corneal biomechanical properties with the Ocular Response Analyzer ${ }^{\circledR}$ (ORA) in African and Caucasian normal subjects and patients with glaucoma. Acta Ophthalmol. 2012;90(2):e118-e124. doi:10.1111/j.1755-3768.2011.02274.x

10. Bueno-Gimeno I, Martínez-Albert N, Gené-Sampedro A, España-Gregori E. Anterior segment biometry and their correlation with corneal biomechanics in Caucasian children. Curr Eye Res. 2019;44(2):118-124. doi:10.1080/02713683.2018.1539181

11. Kamiya K, Shimizu K, Ohmoto F. Effect of aging on corneal biomechanical parameters using the ocular response analyzer. $J$ Refract Surg. 2009;25(10):888-893. doi:10.3928/1081597X-20090917-10

12. Morita T, Shoji N, Kamiya K, et al. Corneal biomechanical properties in normal-tension glaucoma. Acta Ophthalmol. 2012;90:e48-e53. doi:10.1111/j.1755-3768.2011.02242.x

13. Pillunat KR, Hermann C, Spoerl E, Pillunat LE. Analyzing biomechanical parameters of the cornea with glaucoma severity in open-angle glaucoma. Graefes Arch Clin Exp Ophthalmol. 2016;254(7):1345-1351. doi:10.1007/s00417-016-3365-3
14. Shah S, Laiquzzaman M, Bhojwani R, Mantry S, Cunliffe I. Assessment of the biomechanical properties of the cornea with the ocular response analyzer in normal and keratoconic eyes. Invest Ophthalmol Vis Sci. 2007;48(7):3026-3031. doi:10.1167/iovs.04-0694

15. Goebels SC, Seitz B, Langenbucher A. Precision of ocular response analyzer. Curr Eye Res. 2012;37(8):689-693. doi:10.3109/ 02713683.2012.660592

16. Lam AK, Chen D, Tse J. The usefulness of waveform score from the ocular response analyzer. Optom Vis Sci. 2010;87(3):195-199. doi:10.1097/OPX.0b013e3181d1d940

17. Hodapp EPRI, Anderson DR. Clinical Decisions in Glaucoma. St Louis: The CV Mosby Co; 1993.

18. Brusini P, Johnson CA. Staging functional damage in glaucoma: review of different classification methods. Surv Ophthalmol. 2007;52(2):156-179. doi:10.1016/j.survophthal.2006.12.008

19. Burgoyne CF, Downs JC, Bellezza AJ, Suh JK, Hart RT. The optic nerve head as a biomechanical structure: a new paradigm for understanding the role of IOP-related stress and strain in the pathophysiology of glaucomatous optic nerve head damage. Prog Retin Eye Res. 2005;24(1):39-73. doi:10.1016/j.preteyeres.2004.06.001

20. Sullivan-Mee M, Halverson K, Pensyl D, Colonna K, Gerhardt G, Chavez C. Anterior scleral rigidity in primary open-angle glaucoma. Invest Ophthalmol Vis Sci. 2010;51(13):5548.

21. Wang J, Freeman EE, Descovich D, et al. Estimation of ocular rigidity in glaucoma using ocular pulse amplitude and pulsatile choroidal blood flow. Invest Ophthalmol Vis Sci. 2013;54(3):1706-1711. doi:10.1167/iovs.12-9841

22. Furlanetto RL, Park SC, Damle UJ, et al. Posterior displacement of the lamina cribrosa in glaucoma: in vivo interindividual and intereye comparisons. Invest Ophthalmol Vis Sci. 2013;54(7):4836-4842. doi:10.1167/iovs.12-11530

23. Jia X, Yu J, Liao SH, Duan XC. Biomechanics of the sclera and effects on intraocular pressure. Int $J$ Ophthalmol. 2016;9 (12):1824-1831. PMID: 28003987; PMCID: PMC5155000. doi:10.18240/ijo.2016.12.21

24. Brandt JD, Beiser JA, Kass MA, Gordon MO. Central corneal thickness in the Ocular Hypertension Treatment Study (OHTS). Ophthalmology. 2001;108(10):1779-1788. doi:10.1016/s01616420(01)00760-6

25. Gordon MO, Beiser JA, Brandt JD, et al. The Ocular Hypertension Treatment Study: baseline factors that predict the onset of primary open-angle glaucoma. Arch Ophthalmol. 2002;120(6):714-830. doi:10.1001/archopht.120.6.714

26. Wolfs RC, Klaver CC, Vingerling JR, Grobbee DE, Hofman A, de Jong PT. Distribution of central corneal thickness and its association with intraocular pressure: the Rotterdam study. Am J Ophthalmol. 1997;123(6):767-772. doi:10.1016/s0002-9394(14)71125-0

27. Nemesure B, Wu SY, Hennis A, Leske MC; Barbados Eye Study Group. Corneal thickness and intraocular pressure in the Barbados eye studies. Arch Ophthalmol. 2003;121(2):240-244. doi:10.1001/ archopht.121.2.240

28. Mandalos A, Anastasopoulos E, Makris L, Dervenis N, Kilintzis V, Topouzis F. Inter-examiner reproducibility of Ocular Response Analyzer using the waveform score quality index in healthy subjects. $J$ Glaucoma. 2013;22(2):152-155. doi:10.1097/ IJG.0b013e318227e63e1

29. Carbonaro F, Andrew T, Mackey DA, Spector TD, Hammond CJ. The heritability of corneal hysteresis and ocular pulse amplitude: a twin study. Ophthalmology. 2008;115(9):1545-1549. doi:10.1016/ j.ophtha.2008.02.011

30. Shah S, Laiquzzaman M, Cunliffe I, Mantry S. The use of the Reichert ocular response analyser to establish the relationship between ocular hysteresis, corneal resistance factor and central corneal thickness in normal eyes. Cont Lens Anterior Eye. 2006;29 (5):257-262. doi:10.1016/j.clae.2006.09.006 
31. Foster PJ, Broadway DC, Garway-Heath DF, et al. Intraocular pressure and corneal biomechanics in an adult British population: the EPIC-Norfolk eye study. Invest Ophthalmol Vis Sci. 2011;52 (11):8179-8185. doi:10.1167/iovs.11-7853

32. Leite MT, Alencar LM, Gore C, et al. Comparison of corneal biomechanical properties between healthy blacks and whites using the Ocular Response Analyzer. Am J Ophthalmol. 2010;150(2):163-168. e1. doi:10.1016/j.ajo.2010.02.024

33. Sedaghat MR, Mohammad Zadeh V, Fadakar K, Kadivar S, Abrishami M. Normative values and contralateral comparison of anterior chamber parameters measured by Pentacam and its correlation with corneal biomechanical factors. Saudi J Ophthalmol. 2017;31(1):7-10. doi:10.1016/j.sjopt.2016.11.006

34. Ali A. Corneal hysteresis values in normal Egyptian population. Kasr Al Ainy Med J. 2017;23(1):38-42. doi:10.4103/1687-4625.207196

35. Lim L, Gazzard G, Chan Y-H. Cornea biomechanical characteristics and their correlates with refractive error in Singaporean children. Invest Ophthalmol Vis Sci. 2008;49(9):3852-3857. doi:10.1167/ iovs. 07-1670

36. Song Y, Congdon N, Li L, et al. Corneal hysteresis and axial length among Chinese secondary school children: the Xichang Pediatric Refractive Error Study (X-PRES) report no. 4. Am J Ophthalmol. 2008;145(5):819-826. doi:10.1016/j.ajo.2007.12.034

37. Hwang HS, Park SK, Kim MS. The biomechanical properties of the cornea and anterior segment parameters. BMC Ophthalmol. 2013;13:49. doi:10.1186/1471-2415-13-49

38. Wang JK, Huang TL, Pei-Yuan S, Chang PY. Factors affecting corneal hysteresis in Taiwanese adults. Eye Sci. 2015;30(3):89-93.

39. Sharifipour F, Panahi-Bazaz M, Bidar R, Idani A, Cheraghian B. Age-related variations in corneal biomechanical properties. $J$ Curr Ophthalmol. 2016;28(3):117-122. doi:10.1016/j.joco.2016.05.004

40. Knox Cartwright NE, Tyrer JR, Marshall J. Age-related differences in the elasticity of the human cornea. Invest Ophthalmol Vis Sci. 2011;52(7):4324-4329. doi:10.1167/iovs.09-4798

41. Elsheikh A, Geraghty B, Rama P, Campanelli M, Meek KM. Characterization of age-related variation in corneal biomechanical properties. J R Soc Interface. 2010;7(51):1475-1485. doi:10.1098/ rsif.2010.0108

42. Sundaresan Y, Veerappan M, Ramasamy KS, et al. Identification, quantification and age-related changes of human trabecular meshwork stem cells. Eye and Vis. 2019;6:31. doi:10.1186/s40662-0190156-z

43. Spoerl E, Zubaty V, Raiskup-Wolf F, Pillunat LE. Oestrogen-induced changes in biomechanics in the cornea as a possible reason for keratectasia. $\quad B r \quad J$ Ophthalmol. 2007;91(11):1547-1550. doi:10.1136/bjo.2007.124388

44. Uchida K, Himori N, Hashimoto K, et al. The association between oxidative stress and corneal hysteresis in patients with glaucoma. $S c i$ Rep. 2020;10(1):545. doi:10.1038/s41598-020-57520-x

45. Schweitzer JA, Ervin M, Berdahl JP. Assessment of corneal hysteresis measured by the ocular response analyzer as a screening tool in patients with glaucoma. Clin Ophthalmol. 2018;12:1809-1813. doi:10.2147/OPTH.S168032

46. Park JH, Jun RM, Choi KR. Significance of corneal biomechanical properties in patients with progressive normal-tension glaucoma. $\mathrm{Br}$ J Ophthalmol. 2015;99(6):746-751. doi:10.1136/bjophthalmol-2014305962

47. Bayoumi NH, Bessa AS, El Massry AA. Ocular response analyzer and Goldmann applanation tonometry: a comparative study of findings. $J$ Glaucoma. 2010;19(9):627-631. doi:10.1097/ IJG.0b013e3181ca7e01

48. Medeiros FA, Weinreb RN. Evaluation of the influence of corneal biomechanical properties on intraocular pressure measurements using the ocular response analyzer. J Glaucoma. 2006;15(5):364-370. doi:10.1097/01.ijg.0000212268.42606.97
49. Zhang H, Sun Z, Li L, et al. Comparison of intraocular pressure measured by ocular response analyzer and Goldmann applanation tonometer after corneal refractive surgery: a systematic review and meta-analysis. BMC Ophthalmol. 2020;20:23. doi:10.1186/s12886019-1288-6

50. Ehrlich JR, Radcliffe NM, Shimmyo M. Goldmann applanation tonometry compared with corneal-compensated intraocular pressure in the evaluation of primary open-angle glaucoma. BMC Ophthalmol. 2012;12:52. doi:10.1186/1471-2415-12-52

51. Bourne RR, Sukudom P, Foster PJ, et al. Prevalence of glaucoma in Thailand: a population based survey in Rom Klao District, Bangkok. Br J Ophthalmol. 2003;87(9):1069-1074. doi:10.1136/bjo.87.9.1069

52. Wang YX, Xu L, Wei WB, Jonas JB, Acott TS. Intraocular pressure and its normal range adjusted for ocular and systemic parameters. The Beijing Eye Study 2011. PLoS One. 2018;13(5):e0196926. doi:10.1371/journal.pone.0196926

53. Chan MP, Grossi CM, Khawaja AP, et al. Associations with intraocular pressure in a large cohort: results from the UK biobank. Ophthalmology. 2016;123(4):771-782. doi:10.1016/j. ophtha.2015.11.031

54. Foster PJ, Buhrmann R, Quigley HA, Johnson GJ. The definition and classification of glaucoma in prevalence surveys. $\mathrm{Br} J$ Ophthalmol. 2002;86(2):238-242. doi:10.1136/bjo.86.2.238

55. Medeiros FA, Meira-Freitas D, Lisboa R, Kuang TM, Zangwill LM, Weinreb RN. Corneal hysteresis as a risk factor for glaucoma progression: a prospective longitudinal study. Ophthalmology. 2013;120 (8):1533-1540. doi:10.1016/j.ophtha.2013.01.032

56. Susanna CN, Diniz-Filho A, Daga FB, et al. A prospective longitudinal study to investigate corneal hysteresis as a risk factor for predicting development of glaucoma. $A m$ J Ophthalmol. 2018;187:148-152. doi:10.1016/j.ajo.2017.12.018

57. Zhang C, Tatham AJ, Abe RY, et al. Corneal hysteresis and progressive retinal nerve fiber layer loss in glaucoma. Am J Ophthalmol. 2016;166:29-36. doi:10.1016/j.ajo.2016.02.034

58. Congdon NG, Broman AT, Bandeen-Roche K, Grover D, Quigley HA. Central corneal thickness and corneal hysteresis associated with glaucoma damage. Am J Ophthalmol. 2006;141 (5):868-875. doi:10.1016/j.ajo.2005.12.007

59. Narayanaswamy A, Su DH, Baskaran M, et al. Comparison of ocular response analyzer parameters in Chinese subjects with primary angle-closure and primary open-angle glaucoma. Arch Ophthalmol. 2011;129(4):429-434. doi:10.1001/archophthalmol.2011.60

60. Ang GS, Bochmann F, Townend J, Azuara-Blanco A. Corneal biomechanical properties in primary open angle glaucoma and normal tension glaucoma. J Glaucoma. 2008;17(4):259-262. doi:10.1097/ IJG.0b013e31815c3a93

61. Grise-Dulac A, Saad A, Abitbol O, et al. Assessment of corneal biomechanical properties in normal tension glaucoma and comparison with open-angle glaucoma, ocular hypertension, and normal

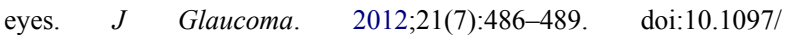
IJG.0b013e318220daf0

62. Bolívar G, Sánchez-Barahona C, Teus M, et al. Effect of topical prostaglandin analogues on corneal hysteresis. Acta Ophthalmol. 2015;93:e495-e498. doi:10.1111/aos.12689

63. Meda R, Wang Q, Paoloni D, Harasymowycz P, Brunette I. The impact of chronic use of prostaglandin analogues on the biomechanical properties of the cornea in patients with primary open-angle glaucoma. Br J Ophthalmol. 2017;101(2):120-125. doi:10.1136/ bjophthalmol-2016-308432

64. Cho AR, Rhew JY, Choi KR; Ewha Institute of Ophthalmology and Optometry. The effects of prostaglandin analogues on the corneal biomechanical factors in normal tension glaucoma. Invest Ophthalmol Vis Sci. 2014;55(13):4234. 


\section{Publish your work in this journal}

Clinical Optometry is an international, peer-reviewed, open access journal publishing original research, basic science, clinical and epidemiological studies, reviews and evaluations on clinical optometry. All aspects of patient care are addressed within the journal as well as the practice of optometry including economic and business analyses. Basic and clinical research papers are published that cover

Submit your manuscript here: https://www.dovepress.com/clinical-optometry-journal all aspects of optics, refraction and its application to the theory and practice of optometry. The manuscript management system is completely online and includes a very quick and fair peer-review system, which is all easy to use. Visit http://www.dovepress.com/ testimonials.php to read real quotes from published authors. 